\title{
Exhibiting the Revolution: Expositions at the Museum of the Revolution in Leningrad in the 1920's and 1930's
}

Lacking an established form of popular legitimacy, the new Bolshevik administration in 1917 set about justifying the heroic struggle of the October Revolution as the foundation narrative for a new perception of revolutionary history. Francois Furet regarded the foundation narrative of October to be the 'universal spell' by which the new Soviet leadership could bring the rank and file to identify with a new conception of their place in the present and their perception of the past. ${ }^{1}$ Frederick Corney's Telling October developed this theme, emphasising that the legitimacy of the Soviet State rested almost solely on how one perceived the 'foundation event' of the October Revolution that the Bolsheviks claimed for themselves. ${ }^{2}$ Only through the correct retelling of this foundational event would the Bolsheviks be able to eliminate dangerous counter-narratives which threatened to underline their tenuous grip on authority. Right from the first formal announcement of the October Revolution, Bolshevik leaders were making a 'concerted effort to frame public understanding of events'. ${ }^{3}$ Numerous methods of public retelling were engendered for the purpose of mythologizing a vision of October and many of these methods involved a carefully structured method of exhibition. Physical traces were curated for this purpose in museums and libraries, whilst the events of October were showcased and dramatized in processions, festivals and public theatre. ${ }^{4}$

Parallel developments were occurring institutionally throughout the formative Soviet period in order to form a controlled narrative of revolutionary history. A Marx Engels Institute was founded in Moscow during 1919 as an academic research facility, quickly amassing over 400,000 books and

\footnotetext{
${ }^{1}$ F. Furet, The Passing of an Illusion: The Idea of Communism in the Twentieth Century. Chicago, IL: University of Chicago Press, 1999, pp.63-93.

2 F.C. Corney, Telling October: Memory and the Making of the Bolshevik Revolution, Ithaca: Cornell University Press, 2004, p.5.

3 lbid, p.15.

${ }^{4}$ Ibid, pp.9-10. N. Murray. "Street Theatre as Propaganda: Mass Performances and Spectacles in Petrograd in 1920." Studies in Theatre \& Performance, 36, No. 3 (November 2016), pp.230-241.
} 
pamphlets. ${ }^{5} 87$ of its 109 staff were historians, committed to maintaining a historical record of the revolution and the Communist Party. A separate Lenin Institute, created in 1923, was even more heavily staffed (158 by 1929), went about collecting and publishing Lenin's complete works in twenty-five volumes between 1924 and 1933. Yet perhaps the strongest example of a refined project to collate and retell the revolution came with the Commission on the History of the October Revolution and the History of the CPSU (Istpart), which had been created by Narkompros (Ministry of Education) in September 1920, but tellingly placed under Central Committee control a year later. Staffed by men with experience in the Bolshevik press, many of which had served in military revolutionary committees directly involved in the Winter Palace coup, the organization was built around the motto 'our attitude to the documents of the revolution must be as active as our attitude towards the events of the revolution'. ${ }^{6}$ Aside from protecting the documentary evidence of the revolutionary movement, Istpart saw themselves as crucial in the struggle to overcome the 'pathetic state of knowledge' that the public had about the party. ${ }^{7}$ Leadership figures in Istpart called for a history of the Russian Communist Party as soon as possible to act as a 'weapon of ceaseless struggle', but they were faced with significant shortages of legitimate evidence and turning what dry material into an 'enticing narrative'. ${ }^{8}$

Istpart was tasked with collecting the past and shaping it into a coherent yet flexible revolutionary narrative. The expansion of this project was rapid, going from 21 bureaus in October 1921 to 72 just a year later. These bureaus were required to report on a monthly basis back to their Moscow headquarters in order to aid 'mapping the revolution'. Building on work by Michel-Rolph Trouillout, Corney argues that this process evidences a clear example of institutions and archives being central to the process of constructing a chosen narrative, rather than being mere passive collectors. ${ }^{9}$

\footnotetext{
${ }^{5}$ The Marx Engels Institute merged with the larger Lenin Institute in November 1931. J. Barber, Soviet Historians in Crisis, 1928-1932. London: Macmillan, 1981, pp. 16-17, p.122.

${ }^{6}$ Corney, p.97.

${ }^{7}$ Ibid, p.106.

8 Ibid, pp.109-110.

${ }^{9}$ M-R. Trouillon, Silencing the Past: Power and the Production of History, Boston, MA: Beacon Press, 1995, pp.24-28.
} 
Undeniably the process of fashioning a controlled narrative influenced the growing construction of exhibitions and museums devoted to the October Revolution and the history of the revolutionary movement. Alongside Istpart and the Marx Engels Lenin Institute, this represented part of a Bolshevik led effort to 'institutionalize October'. ${ }^{10}$

This article focuses on the expanding network of historical-revolutionary museums which emerged after 1917, which until recently had attracted little attention aside from institutional museum specialists within Russia itself, such as Natalia Semenova and Elena Solomakha, who have concentrated primarily on resource limitations, expropriation of artefacts and the breaking up of collections. ${ }^{11}$ Instead, this article emphasises their functional role, specifically the communication of new cultural and ideological values to visitors through exhibiting the history of the revolutionary movement. By focusing on the State Museum of the Revolution (GMR), the first museum of revolutionary history in Russia, this article places the role of the museum within this shared quest to collect and curate revolutionary history, but with the greater responsibility of public engagement. The GMR offers a uniquely strong example of the struggle between institutional autonomy, the efforts of activists and the role of the new government over access to and the presentation of revolutionary history, especially the memory of October and the role of the Bolshevik Party.

\footnotetext{
${ }^{10}$ Corney, p.100.

${ }^{11}$ E. Solomakha, "The Hermitage, Gosmuzeifond, and Antikvariat." Canadian-American Slavic Studies 43, no. 14 (Spring-Winter 2009), pp.131-160. N. Semenova, "A Soviet Museum experiment", Canadian American Slavic Studies, 43, Nos. 1-4 (Spring-Winter 2009), pp.81-102.
} 
At the All Russian Museums Congress in Petrograd in February 1919, Anatoly Lunacharsky spelt out the need to 'show the masses that the museum is essential to them' ${ }^{12}$ At the same Congress, the academic Naum Marr recognized the extraordinary potential of museums to be used for a new period of enlightenment. 'Now that nothing is private', Russia's cultural wealth could be shared for all. Both men understood the remarkable potential of the museum as a central component of the cultural apparatus by which the masses could be educated. The result was that existing museum holdings swelled following the nationalization decrees of 1918 and scores of palace museums were shaped from formerly private collections. In the immediate period following the October Revolution, the number of museums in Russia doubled between 1918 and $1920 .{ }^{13 * *}$ This rich inheritance would be meaningless unless museums were able to reflect the revised attitude towards Russia's history; especially the epoch defining events that had resulted in the victory of the revolutionary movement. With this remit in mind, Narkompros formed a department specific to the management and reorganization of the museum network, Glavmuzei. In the decade that followed the October Revolution, over 100 historical-revolutionary museums were opened in Russia.

The Museum of the Revolution was established by the Petrograd Soviet on $9^{\text {th }}$ October 1919. The museum was given one of the most historically significant places in the site of the revolution: the Winter Palace. There, the museum was entrusted with safeguarding the revolution by gathering and documenting the material evidence of revolutionary struggle. The GMR was creating collections from anew, creating a reverence for events and concepts that had previously not previously been

\footnotetext{
12 Semenova, p.81.

${ }^{13}$ S. Smith, 'Cultural Heritage and the People's Property: Museums in Russia 1914-21' (pp.403-423), p.416, in M Frame, S Marks, M Stockdale and B Kolonitskii et al. Cultural History of Russia in the Great War and Revolution 1914-22. Bloomington: Slavica, 2014.

*Petrograd was renamed Leningrad shortly after Lenin's death on 26 th January 1924.

** Note: There were 457 museums in total in 1920.
} 
given a permanent visible public platform. The inimitable collections, coupled with the unique location, gave the GMR the responsibility for the presentation of revolution to the general public.

The greater function of the Museum of the Revolution was to 'become a central museum that can fully and comprehensively illuminate the progress and development of revolutionary movements on a global scale'. ${ }^{14}$ Therefore it was not merely a remit to justify and reflect October itself, but for the history of righteous historical struggles for social, economic and political emancipation. This implied an explicitly educational function. The view that only a sustained period of education would remove the shackles of chauvinism and illiteracy in order to enable the masses to fulfil their potential had indeed unified a greater number of intellectuals from across the political spectrum. Likewise, the GMR was established in such a way that it did not make the Bolshevik claim to the revolution exclusive. The creators of the museum came from a variety of political parties, the humanitarian intelligentsia and the Narodnik (Populist) movement, though the Petrograd Soviet did immediately position the true authority of the collegium behind powerful Bolsheviks. These leaders included Anatoly Lunacharsky (Commissar for Education) and Grigory Zinoviev (Petrograd Soviet Chairman and Politburo member). Whilst most of these men had clear Bolshevik credentials, suggesting a desire to enshrine the revolution in a manner of their own choosing, the collegium also included pragmatic appointments, such as the inclusion of leading academic Sergei Oldenburg, a former Kadet, and the first director, Mikhail Kaplan, a man not suited to the Bolshevik vision, having lived abroad and born into a family of formerly good standing, placed duty above concerns of party allegiance. $^{15}$

\footnotetext{
${ }^{14}$ L.A. Misko, 'Ekskursiya v proshloye: ekskursionnaia rabota v gosudarstvennom muzee revoliutsii' (Excursion into the past: Excursion work in the State Museum of the Revolution 1921-39), in A.M. Kulegin (ed), GMPIR: 90 years in the space of history and politics, 1919-2009. SPb.: Norma, 2010, p.76.

${ }^{15}$ V.R. Leikina-Svirskaia, 'Iz istorii Leningradskogo muzeia revoliutsii' (From the history of the Leningrad Museum of the Revolution), in Essays on the history of the museum business in Russia: Proceedings of the Research Institute of Museum Science, Issue III, Moscow: Soviet Russia, 1961, p.55. Also, PV Ushakov, 'Obychnaya zhizn' v neobychnuiu epokhu' (Ordinary life in extraordinary times), A.M. Kulegin (ed), GMPIR: 90 years in the space of history and politics, 1919-2009. SPb.: Norma, 2010, p.84.
} 
Whilst senior Bolsheviks held predominance in the collegium, the roots of the museum lay in the desire for revolutionaries to record their long struggle and to communicate this to a population not fully versed in the long arc of their history. The original collection of artefacts was built around one secretly gathered by Mikhail Novorusskii, a veteran of the revolutionary movement, since the Revolution of 1905. Speaking at the museum opening in 1920, Novorusskii reflected that he 'never stopped collecting certain items...they served as a memorial to the lives of comrades' ${ }^{16}{ }^{T h i s}$ collection of items was sent to Berlin, 'where the rudiments of the Museum of the Revolution were laid' until such a time when they could be displayed in Russia itself. Great efforts were also made to engage the public in the process of building the museum. In May 1919, Petrogradskaia Pravda lauded the importance of creating a museum in the 'former chambers of bloody emperors and at the tables where they may have signed death sentences', whilst envisioning portraits of martyrs handing 'like an eternal reminder of retribution' ${ }^{17}$ Likewise the press called to the public in sourcing collections. The same newspaper gained a strong response from Petrograders when asking for 'monuments of the Russian Revolution', especially from revolutionary veterans.

In this initial period, a relatively supportive balance was achieved between Soviet institutions, museum specialists and the cooperation of the public, often through civic groups. Members of one such group, the Society of Former Political Prisoners and Exiles, made up of prominent participants of the revolutionary movement, were part of the collegium which created the museum. The society conducted scholarly research, preserved collections of artefacts and materials and published the Katorga i ssylka (Hard Labour and Exile) journal, which directly contributed to the development of the GMR. The Petrograd Soviet had agreed to provide 'all materials relating to Soviet construction, as well as materials on the history of the revolutionary movement', whilst the museum was provided

\footnotetext{
${ }^{16}$ E.G. Artemov, 'Opyt proshlogo vzgliad v vudushchee: osnovnyye istoricheskie etapy deiatel'nosty muzeia' (Experience of the past: the main historical stages of the Museum), in A.M. Kulegin (ed), GMPIR: 90 years in the space of history and politics. 1919-2009. SPb.: Norma, 2010, p.7

${ }^{17}$ A Konivets, The Winter Palace in the Post-Revolutionary Years: the opening of the Museum of the Revolution. History of Petersburg, 2010, No.2, p.66.
} 
with the use of a special agitation train in order to collect materials from Civil War battlefields. Collections teams ventured as far as the Caucasus, Ukraine and Belarus, whilst bureaus were set up in places such as Kharkov, where teams continued to gather materials during the early 1920 's. Often items were found closer to home, with one staff member recalling the tale of chasing a man wearing Denikin's greatcoat across the icy River Neva in order to secure it for the Civil War department. ${ }^{18}$ Despite being allocated early privileges, this trend did not continue, especially in terms of financial support and respect for the museum profession. The first Director, Mikhail Kaplan, recognized that 'the Bolsheviki do not care about merit...their chief concern is a membership card'. Department leaders, such as Head of Collections, Maria Karnaukhova complained about the 'scarcity of museum funds' and the desperate state of working conditions, namely the 'appalling' cold; her colleague Elizabeta Yakovleva, in charge of the section on the Social Democrats complained of valuable books and documents being gnawed by rats. ${ }^{19}$ State funding for the museum barely covered staff wages, which despite their required expertise, left staff struggling to make ends meet.

\section{Expositions at the Museum of the Revolution}

From its beginnings in the Winter Palace, the museum was divided into four departments. ${ }^{20}$ The first, starting from the Saltykovsky entrance hall, focused on the 'underground period', emphasising the peasant uprisings from the $17^{\text {th }}$ century onwards (including the Pugachev uprising) and guiding the visitor until the events of 1905 . This exposition had rooms on the Decembrist revolt, the mid-19 ${ }^{\text {th }}$ century, populism and the 'birth of social democracy', including of course, the Russian Social Democratic Labour Party (RSDLP). The second department dealt with the development of the revolutionary movement in Europe, highlighting the Paris Commune and the role of the International. The third section, with the visitor entering from the famous Jordanian staircase, encompassed the 'Imperialist War' beginning in 1914, the February and October revolutions of 1917

\footnotetext{
18 Leikina-Svirskaia, p.55.

${ }^{19}$ GMPIR F.VI D.45/1, Memories of employees, p.8 and p.17. Ibid, p.18.

${ }^{20}$ V.D. Zamirailo, Kratkii putevoditel' po muzeiu (Short guide to the museum), Leningrad, c.1928, pp.4-9.
} 
and the Civil War. Here, as might be expected, these rooms were in perhaps developed in the greatest detail, devoting significant sections to themes such as 'the fall of autocracy', the 'organization of the masses' and the 'politicization of the army during the First World War', and rooms devoted to different theatres of the Civil War. Finally, the museum had a fourth department which reflected upon the victims of forced labour and penal servitude. These themes would be explored in greater detail once the Museum of the Revolution had fully opened its branches at the Peter and Paul Fortress (1924) and the Shlisselburg Fortress (1928). All branches, but especially the latter, had strong connections with the Society of Former Political Prisoners and Exiles, who were central to original efforts to build museum collections and to provide guided excursions.

The first exhibitions, opened in November 1922, were not single expositions and instead they maintained separate, yet quite obviously related themes. Each department maintained their own collections, held responsibility for their own exhibitions and their displays were dictated to a large extent by recently collected material. ${ }^{21}$ The creation of expositions relied heavily on their own scientific developments and the framework of Marxist-Leninist theory. In certain departments, the staff were drawing upon personal experience of the themes - many had been participants in revolutionary events and the Civil War. They were also participating in unchartered territory in that the historiography of such events was still being formed. The historiography was being created in tandem with collecting and design work, meaning that the early exhibitions were remarkably pliable.

If the contemporary nature of revolutionary events initially rendered the Civil War section fluid in its development, then subjects without a clearly determined narrative, such as the use of masonic objects in the Decembrists display gave another example of unprecedented curatorship. As evidenced in the museum guides of 1928 and 1933, Masonic objects certainly remained in the displayed collection for at least a decade, despite the broadly negative attitude held by communists

\footnotetext{
${ }^{21}$ S.L. Spiridonov, 'Tema Grazhdanskoi voiny v Rossii v Ekspozitsii GMR-GMPIR' (The theme of Civil War), in A.M. Kulegin (ed), GMPIR: 90 years in the space of history and politics, 1919-2009. SPb.: Norma, 2010, p.127.
} 
towards freemasonry. The lack of records means that there are no definitive answers as to the logic of why they were utilised, but it appears that it was the first attempt to use Masonic artefacts to discuss a phenomenon in Russian History, rather than purely as objects of wonder. ${ }^{22}$ The section was formed in 1925, but removed ten years later when the Bureau of the Leningrad City Council Committee of the Communist Party formed a resolution which criticised 'serious methodological errors', leading to their retraction from display and eventual transfer to the Hermitage in $1954 .^{23}$ These items were used in conjunction with the exposition on the Decembrists and the revolt of 1825, focusing especially on the proliferation of secret societies in the first quarter of the nineteenth century after the French Revolution 'had showed them a revolutionary way out' and the contradictions which had emerged 'between the demands of the capitalist economy developing in Russia and the old Feudal way of life'. ${ }^{24}$ The displays, as described by the 1928 guide to the museum, in addition to articles published by pedagogical staff the following year, fully suggest that the exhibition openly illustrated the importance of the Decembrist participation in masonic lodges. Freemasonry was portrayed as a 'cosmopolitan brotherhood' with the objective of transforming life through 'moral improvement' ${ }^{25}$ Importantly, the primary driving force was the desire for 'equality of all people'. But just as central, as a result of their independence from both Church and State, was the ability of Freemasons to explore freedom of conscience, and therefore freedom of thought. ${ }^{26}$ In an article written by Nikolay Druzhinin for the Museum of the Revolution collection of articles in 1929, the bold direction found within Freemasonry paved the way for the doctrine of liberal individualism and political parties.

\footnotetext{
${ }^{22}$ L.V. Khozeevich, 'Masonskiie predmety v GMR- rekonstruktsiia kontseptsii eksponirovaniia' (Masonic objects in the Museum of the Revolution), in A.M. Kulegin (ed), GMPIR: 90 years in the space of history and politics, 1919-2009. SPb.: Norma, 2010, p.39.

${ }^{23} \mathrm{lbid}$.

${ }^{24}$ Zamarailo, Short guide to the Museum, p.14.

${ }^{25}$ N.M. Druzhinin, 'Masonskie znaki Pestelia', in Museum of the Revolution: Second Collection of Articles, Leningrad, 1929, pp.40-41.

${ }^{26} \mathrm{lbid}$.
} 
The use of masonic objects at the Museum of the Revolution showed an ability by the museum staff to be innovative, especially in updating their exhibitions in tandem with the developing historiography. A case in point can be found with the support of Nikolay Druzhinin's research in the late 1920's. Druzhinin, employed since 1926 to tackle the many problems of museology and methodology within exposition work, extended the existing knowledge of freemasonry and the Decembrist movement from the renowned amateur historian and populist, $\mathrm{VI}$ Semevskii. ${ }^{27}$ In line with Druzhinin's argument, the expositions increasingly reflected freemasonry as a school of noble conspiracy. Developed focus was given to the causal movements leading to the activities of the Decembrists, the agrarian crisis of the early nineteenth century and the social composition of the Decembrists themselves. The article by Druzhinin portrayed Pavel Pestel's lodge Soyuz Spaseniya (the Union of Salvation) as filled with members of noble families 'imbued with the mood of cabin liberalism', increasingly drawn to 'casual conversations' ${ }^{28}$ This sparked a reconceptualization of the display and even the search for new artefacts. The preserved collection of Pestel was a key part of excursions through the museum and enabled visitors to gain a clear insight into the formative stages of a secret political society, dwelling on Pestel's preference for masonic societies as a 'suitable shell for a militant, strictly disciplined organization', with Alexander Muravyov noting that it 'seemed relatively easy to take advantage of the ready-made, more or less homogenous closed cell'.

Druzhinin's work in examining the belongings of Pestel had a direct impact in GMR display, with aprons, daggers relating to the French masonic system, aprons, notebooks and letters of the Swedish masonic system placed as a central element of the Decembrist display. In essence, the museum curators were keen to recognize Druzhinin's research as at the forefront of understanding the earlier stages of the revolutionary movement. It was a shared quest for the curators, alongside

\footnotetext{
${ }^{27}$ V.I. Semevskii, Dekabristy-masony: Minuvshie gody, St. Petersburg, 1908, pp.379-433. Also, P. O'Meara, The Decembrist Pavel Pestel: Russia's First Republican, London: Palgrave Macmillan, 2003.

${ }^{28}$ Druzhinin, 'Masonskie znaki Pestelia', pp.16-17.
} 
dynamic historical research of the day. Druzhinin's fate, like the more dynamic early curating of the GMR, would not survive the demand for orthodoxy, and his work was publicly criticised by M.N. Pokrovsky, the dominant force in the historical sciences, in Pravda in 1929. Druzhinin was refused to right to defend himself, with a reply letter refused publication, and he was even arrested in 1930 and exiled to Siberia before being restored to academic life. ${ }^{29}$ During his time at the museum, he published a monograph on Nikita Murav'ev, amongst a wider catalogue on the Decembrists and the Northern Society, in which he contended that the main objective of the Decembrists was 'radical change of the form of government and an overall social reform' rather than merely regicide, a wider scope than had been previously argued. ${ }^{30}$

The representation of masonry showed the potential of the museum's exhibitions to be at the forefront of drawing new conclusions which contributed to new ground in the historiography. Other sections were more carefully guarded and more acutely aware of the bearing that the topics had on a contemporary perception of the revolutionary movement. The Guide to the 1905 department at the Museum of the Revolution (1931) is representative of the need to provide a clear link between the events of 1905 and the seizure of power in October 1917, which effectively formed the culmination of the exhibition. Hence the department was designed with Lenin's analysis, that 'without a dress rehearsal' (i.e. 1905), the success of the October Revolution would not have been possible. A new effort to distinguish 1905 led to a newly opened, updated exposition in 1930, marking the $25^{\text {th }}$ anniversary of the December uprising in Moscow. ${ }^{31}$

The 1905 department was constructed with clear educational navigation in mind, both in terms of visitor understanding and in the suggestion that major lessons were learnt by the revolutionaries and had been disseminated in order to ensure success in 1917. From 1930, the

\footnotetext{
${ }^{29}$ V.N. Abrosimova, 'Pravda vsegda odna! Pis'ma akademika N.M. Druzhnin' (The truth is always alone!), in http://ihst.ru/projects/sohist/document/abr00vr.htm (last viewed 01/10/2018).

${ }^{30}$ N.M. Druzhinin, 'Dekabrist Nikita Murav'ev: Revoliutsionnoie dvizhenie v Rossii v XIX veke', in Izbrannyie Trudy, Moscow, 1985, p.73.

${ }^{31}$ S.I. Chukhman, Otdel 1905 goda $v$ gosudarstvennom muzeie revoliutsii v Leningrade (Department of 1905 in the State Museum of the Revolution in Leningrad), Leningrad, 1931, p.4.
} 
department had clearly defined elements; (1) 'The beginning of the revolution', (2) 'The urban movement acquires a new ally in the revolutionary peasantry', (3) 'Whilst the proletariat fights, the bourgeoisie sneaks into power', 'The revolution on the rise: the labour movement erupts', and (5) 'The zenith of the revolution and the beginning of the reaction'. The first room, 'The beginning of the revolution', provides a microcosm of how the museum expositions sought to be effective in their distillation of complex revolutionary history. Immediately upon entering the room, a number of diagrams clarify the economic and political situation facing the country, including the fall in wages during 1904 , followed by a satirical judgment on the right hand wall, capturing the heinous social structure of Russian society in the form of a social pyramid. The use of visual representation continued with photographs capturing the assembly of factory workers and strikes at the Putilov Plant from January 1905. The arrangement of the exposition enabled a progressive experience for visitors, one typical of the museum's approach. First a statement of context, a justification of grievances, both in conclusive, factual terminology, and in terms of broad consensus and opinion. This would then lead to a development of an emotional tone, often with the use of art. In the case of the first 1905 room, this included Ivan Vladmirov's The shooting of the workers at the Winter Palace on January 9, 1905 and the original cast from which Matvey Manizer's bronze relief was created for Monument to the victims of $9^{\text {th }}$ January 1905.

The following room, focusing on the spread of revolution, enforces the trend from the late 1920 's towards the museum making greater use of emotive art, giving a more romanticised tone to expositions. The GMR employed its own artists to this end, utilising their work where there was need for an artistic interpretation of events. Olga Tauber, a recent graduate from the Leningrad Academy of Arts, was one such example, joining the museum in $1927 .{ }^{32}$ Her main work in this room was in the form of a model which illustrated a shortage of land in the countryside for the peasants, assisting the

\footnotetext{
32 'Biography of O.N. Tauber', in http://tramvaiiskusstv.ru/skulptura/spisok-khudozhnikov/item/1159-tauberolga-nikolaevna-1899.html (last viewed 01/10/2018).
} 
following photographs which depicted the struggle of the peasants against landowners. ${ }^{33}$ The sculpture model strides a position somewhere between the menacing implication of revenge, and the taste of black humour as the oversized peasant stands tall over the land. Yet Tauber's original sculpture reflects a trend that had begun in the last few years of the 1920 's, whereby the pressure to reform shifted the emphasis of the museum's social function, introducing what Artemov calls 'vulgar sociology' and the denial of 'museum specificity'. ${ }^{34}$ Instead of the primacy of original collected artefacts, the emphasis was increasingly placed on an orthodox dissemination of history for functional, educational purposes. A final reasoning for the museum looking towards original artwork like Tauber's model can also traced to the lack of available unique objects. Before the end of 1929, the significant collection of archival material on the history of the revolutionary movement the museum had built up throughout the 1920's had been transferred to the Moscow central archives or Leningrad regional archives. ${ }^{35}$

The restructuring of the State Museum of the Revolution in Leningrad (GMPIR) as a result of the First Museum Congress of the USSR in December 1930 effectively created a more centralised oversight over museum methodology. ${ }^{36}$ For museum exhibitions, but historical and revolutionary exhibitions in particular, it meant replacing existing methods of constructing expositions with a 'propaganda approach to the display of historical phenomena'. Moreover, with the party insisting upon the intensification of class struggle in the period of socialist construction, the will of the party was brought more directly into the field of museum activities. Taking the 1905 department as means of an example clarifies the impact of reform, as curators struggled to meet the demands of the First Museums Congress and the Commissariat of Education instructions that placed the 'Marxist-Leninist display of materials on the history of the revolution' as the main task of the museum. ${ }^{37}$ Given the

\footnotetext{
${ }^{33}$ Chukhman, p.8.

${ }^{34}$ Artemov, Experience of the past, p.10.

${ }^{35}$ GMPIR F.VI. D.45/1/Vospominaniia (Memories), p.8.

${ }^{36}$ Renamed in 1927 . Unless the context specifically requires the reference GMPIR, the default acronym will remain GMR in this text.

${ }^{37}$ Artemov, Experience of the past, p.10.
} 
directives of the First Museums Congress, the expositions within the 1905 department and indeed the 1931 guide act as strong evidence of the shift towards upholding the place of the Bolsheviks as a consistent presence in the two decades prior to October 1917. The exhibition presentation suggests that there is no question of their importance in 1905 , with the Third Congress of the RSDLP offering ample evidence of the revolutionary Marxism of the Bolsheviks struggling against the 'stubborn resistance' of the Mensheviks. ${ }^{38}$

The process of ensuring that historical and revolutionary museums enlightened its visitors along Marxist-Leninist lines branched out into the use of publications built primarily around the expanding collection of photography and original artwork in the museum. Created from Moscow equivalent of GMPIR, Museum of the Revolution School book series contained visually stimulating artwork in the museums collection, supported with a thorough narratives to educate readers. One such publication, focusing on the 'development of capitalism in Russia and the revolutionary struggle of the working class' between 1885 and 1905 , clearly maintains an educational ambition, particularly appealing to students of art or even teachers with an interest in disseminating the historical period. ${ }^{39}$ Alongside emotive and distressing original paintings, like Shooting by Sergei Ivanov, a participant in the 1905 Moscow uprising, the book imparts cleverly placed quotations from Lenin and a picture section dating his activities across the aforementioned period. Publications like this, alongside the efforts in revolutionary museums themselves, sought to join the orthodox MarxistLeninist history with the popularization of approved artwork.

The requirement to create Marxist expositions offered the most significant factor behind the evolution of GMR exhibitions throughout the 1920's. Yet there were other practical and critical considerations that also led to modernization. Andrianova argues that initial expositions suffered somewhat from the task of creating permanent exhibitions because of a failure to moderate, with

\footnotetext{
${ }^{38}$ Chukhman, p.10.

${ }^{39}$ S.I. Mitskevich, Muzei revolutsii - Shkole (Museum of the Revolution - [For] Schools), Leningrad, 1931, p.2.
} 
almost everything collected put into displays. ${ }^{40}$ An exhibition on 'White Terror during the Civil War', which focused primarily on Denikin's troops, had been constructed with materials brought by the expedition of museum to the south of Russia. ${ }^{41}$ In this exhibition, the museum worked closely with historian P.A. Schegolev, a great expert, but one who 'did not fully know and understand the museum business'.$^{42}$ The exhibition had many clothing items and the nature of the layout was perceived as awkward or unclear. Comments from other staff recognized that the exhibition hall appeared as an 'open book', with visitors required to read dense portions of text. Other staff minced no words at all, reflecting on the exhibition design as 'poor', arguing some of the works shown were 'anti-artistic'.${ }^{43} \mathrm{~A}$ jubilee exhibition celebrating the 25th anniversary of the RSDLP was dominated by a deluge of quotations and slogans, producing 'outright boredom' on the faces of visitors. ${ }^{44}$ Exhibition design of this period was characterized by handicraft. Staff recollections discuss the wellknown 'Uncle Yasha' (Y.V. Zolotov), the permanent assistant who combined the roles of carpenter, locksmith, framer and designer. ${ }^{45}$

The approach to exhibition design was of course limited significantly by the acute lack of funding, but slowly innovations started to bring progress during the middle of the decade. Coloured borders signified or distinguished the displayed artefacts: black for Kadets or Monarchists, pink for SR's and Mensheviks, yellow for Bolsheviks. The museum also moved away from the use of flat diagrams by the end of the decade, whilst quotes from textbooks were not used, and every position was in some way highlighted and illustrated. ${ }^{46}$ Funding constraints still required staff to be thrifty in their quest to make improvements. An agreed weakness in the museum was the chronic shortage of clothing, leading to forays into the local flea markets to find illustrative material, which filled gaps in

\footnotetext{
${ }^{40}$ GMPIR F.VI D.45/1, Report, p.17.

${ }^{41}$ Leikina-Svirskaia, p.57, 64.

${ }^{42}$ E.Y. Andrianova, 'Muzei stremilsia sozdavat' marksistskiie ekspozitsii' (The Museum sought to create Marxist expositions), in A.M. Kulegin (ed), GMPIR: 90 years in the space of history and politics. 1919-2009. SPb.: Norma, 2010, p.69.

${ }^{43}$ GMPIR F.VI D.45/1, Memories, p.17.

44 Ibid.

${ }^{45}$ Ibid, p.18.

${ }^{46}$ GMPIR F.VI D.45/1, Report, p.23.
} 
the display of socio-economic background of the required era. ${ }^{47}$ Spiridonov's research into the work of the changing display of Civil War materials at the museum argues that the permanent exhibitions of all departments were already functioning well by 1927 , but that ongoing restructuring was taking place due to a need for 'deeper scientific study' and the central goal of a systematic display on the history of the revolutionary movement had still not been attained..$^{48}$

As was highlighted previously, large-scale reform took place in light of the First Museums Congress at the end of 1930. Changes were made to the scientific approach and exposition work. The Civil War department was singled out for reform, with changes required to meet the 15th anniversary of Soviet power. From 1932, the exhibition was developed around a themedchronological approach, reflecting the key events of the Civil War, beginning with January 1918 and finishing with the formation of the USSR in December 1922, aiding a clearer historical outline. If earlier incarnations of the Civil War department had a propaganda element, it now became a predominant emphasis. Visual aids on the history of the Bolshevik Party were now central to the exhibition. Slogans, diagrams, quotes and diagrams, as well as the now lessened numbers of artefacts, only reinforced this visual agitation. ${ }^{49}$ Even the early signs of a growing personality cult around Stalin were starting to seed, with his quotations and a Lenin-Stalin relief - but this was not a predominant feature at this stage. ${ }^{50}$ Even with the trend to move away from original artefacts, the staff working on the updated 1932 display felt it necessary to 'materialize the exposition' and 'saturate the exposition with authentic things'. This led to the use of life-size imitation figures dressed in Civil War clothing. One such scene included a White Guard officer, a figure in civilian clothing and an English officer drinking for a 'single and indivisible' Russia. ${ }^{51}$ In the early years of the 1930 's, with indecision between the previous reliance on authentic materials and the new trend to

\footnotetext{
${ }^{47}$ GMPIR F.VI D.45/1, Memories, p.18.

48 Spiridonov, p.127. Leikina-Svirskaia, pp.68-69.

${ }^{49}$ E Yakovleva, S Chukhman, V Leikina, Gosudarstvennyi muzei Revoliutsii v Leningrade: Kratkii putevoditel' po otdelam (Museum of the Revolution - a short guide by department), Leningrad, 1933, pp.19-33.

${ }^{50} \mathrm{lbid}, \mathrm{p} .27$.

${ }^{51}$ Leikina-Svirskaia, pp.69-70.
} 
create models or propaganda displays, the 'theatrical exposition' became commonplace. LeikinaSvirskaia reflected back on this trend in the museum, noting that 'the confusion of genuine monuments with theatrical props was later justly condemned' ${ }^{52}$ Another growing practice was the emphasis on 'domestic fragments', attempts to recreate living conditions that evoked a certain time. For example, one fragment created the atmosphere of a Civil-War era Petrograd worker, complete with leather jacket hanging from the wall, documents including propaganda posters and food cards, whilst a burzhuika (stove) completed the scene..$^{53}$ Illustrative methods presupposed the presence of exposition materials that were not genuine, creating opportunities to discuss topics that were too difficult to effectively evidence through exhibits. Such visual aids were used widely in the early 1930 's, perhaps most notably in the shape of the huge papier-mache figures (or interventionists) which wriggled from the ceiling, followed by a relief map of Russia where foreign imperialists were ready to gorge upon the bounty of Russia's plentiful natural resources.

During this period, the Civil War department also used what might be deemed 'interactive' displays. A model designed to show the Bolsheviks as the real representatives of the peasantry in the short-lived Constituent Assembly (1917-18), despite not having a majority. The model contained representatives from each major party, differing in size depending on their number of deputies. Behind each of the party representatives, a Bolshevik worker, backed by a mass of peasants, appeared with a 'decree on land', and lit up so that a silhouette was created over the scene. ${ }^{54}$ Another display with moving parts showed the so-called democratic counter-revolution, preparing the ground for the White Guards. The figure of the Socialist Revolutionary stood on a throne with a banner of democracy in his hands, hidden under a hollow cloak by a gallows. With a lever turn, a hidden mechanism was triggered, the Socialist Revolutionary was thrown by a general's boot, and

\footnotetext{
$52 \mathrm{lbid}$, p.71.

${ }^{53} \mathrm{lbid}$, p.72.

${ }^{54}$ Spiridonov, p.129.
} 
Admiral Kolchak appeared on the throne. Now the gallows lay in his hands, whilst the banner of democracy lay at his feet. ${ }^{55}$

The radical restructuring of the early 1930's was certainly not limited to the Civil War department. A sign of the pressure applied by the People's Commissariat of Education, a circular letter was sent to all museums in March 1933 demanding that they reflect on the results of the First Five Year Plan and the goals of the Second Five Year Plan in their expositions. Yakovleva recalls the effort to react to the First Five Year Plan. In the anteroom, 'a large, moving circle layout' was constructed, with 'slides and models showing the data of industrial and agricultural growth'.${ }^{56}$ In the frenetic push to get the expositions ready, the staff struggled with the 'grief of electrified layouts...they were built with handicraft and came into disrepair at amazing speed'. The museum staff took every effort, creating models that reflected historical changes in statistics and 'complex socio-economic processes'. Models made with 'painted plywood figures depicted the stratification of the village' showed that this was still time whereby innovation was required without expense. Similarly, photographs 'were subjected to colouring by hand'. ${ }^{57}$

Museums were tasked with 'investigating the state and the struggle for quality in the national economy and cultural construction in their region'.58 They were required to organize appropriate classes with workers and collective farmers. All museums faced the impact of distorting and displacing their traditional methodology, their work with visitors and of course their exhibition layout and content. Despite this shift, with the object moving further into the background against the emphasis on agitation, Artemov argues that 'a number of historical and revolutionary museums struggled for the right to maintain the principle of building expositions which provided for a

\footnotetext{
${ }^{55}$ Leikina-Svirskaia, p.73-74

56 GMPIR F.VI D.45/1, Memories, p.18.

57 Ibid.

${ }^{58}$ Artemov, Experiencing the past, p.10.
} 
harmonious combination of genuine objects with a minimum of auxiliary material'. ${ }^{59}$ In this struggle, GMPIR 'took an active part' and maintained authentic exhibits as a leading element of expositions. ${ }^{60}$

This struggle had been hardened with the publication of Sovetskii Muzei (Soviet Museum) by the People's Commissariat of Education in 1931. In the very first issue, the article 'On the tasks of the Soviet Museum', clearly displayed an antagonistic position towards any institution considering dissent. The article derided museums that had resisted reform and the demands of the wider Cultural Revolution; 'While remaining sections of the cultural front passed one after another from the restoration period to the reconstructive one, some museums experienced their abstractly collective and protective period' ${ }^{61}$ The article accused some museum institutions of 'guarding themselves from the socialist construction of the museum'. It attacked 'individual museum exhibits' that had 'linked their fate with the doomed past', whilst other museum workers had gone 'hand in hand and shoulder to shoulder' with the Bolsheviks and the working class. ${ }^{62}$ The article went on to argue in support of the museum as a 'political and educational complex', not just recognizing the events of the past, instead acting to 'help revolutionary understanding and bring revolutionary action' ${ }^{63}$ Their support was thrown fully behind 'restructuring our museums on the basis of dialectical materialism' and against the 'ideological distortions of Marxism' ${ }^{64}$

Recognizing that they could not ignore the magazine, V.R. Leikina contributed 'New exhibition in the Leningrad Museum of the Revolution' to the sixth issue later that year. Leikina gave a lengthy description of the exhibition, supported by photographic evidence. Leikina asserted that the museum were seeking to build expositions in a new way, avoiding 'flat diagrams (and)....unreadable quotations', as well as coloured background decorations and a range of methods

\footnotetext{
59 Ibid.

60 Ibid, p.11.

${ }^{61}$ Sovetskii Muzei, 1931, No.1, p.4.

62 lbid, p.5.

63 Ibid.

64 Ibid.
} 
best suited to the modern era. ${ }^{65}$ Leikina concluded that the museum had found that the best Marxist analysis was achieved by using modern sources and by relating the 'evaluation of historical phenomena in the past to the tasks of the proletarian revolution' ${ }^{66}$

Following Leikina's defence, an article by S. Livshits ('The history of class struggle and its reflection in museums') drew comparison between the Museum of the Revolution in Leningrad and Moscow. Livshits certainly recognized both museums for their assessment of 'objectivism' in the display of the past, but the critical review judged the 'Marxist illumination to be better in the Moscow museum', despite some appreciation towards Leningrad. ${ }^{67}$ 'The Leningrad Museum of the Revolution remains without a domestic background showing how workers and peasants, landlords and capitalists lived' ${ }^{68}$ Little is known about the reaction to the articles, or if they led directly to the reforms that followed, but the articles of Sovetskii Muzei give a definitive pattern of the pressure faced by museums and indeed cultural institutions in the early 1930 's.

\section{'Removing the old manual': The museum after 1935}

Reflecting back on how he came to be appointed as Director of the Museum of the Revolution in May 1935, Sergei Avvakumov described how 'the staff of the museum was stunned by the decision of the Party Committee' ${ }^{69}$ Preceding his appointment and the decision to close the museum, there had been a 'thorough examination of the museum, (and) its expositions'. The Regional Party Committee concluded that 'the expositions of the Museum of the Revolution were vicious, that they greatly exaggerated the role of Populism in the history of the revolutionary workers movement in Russia, and diminished and distorted the role of the Communist Party'. 'The Museum was closed. The old leadership was removed'.$^{70}$

\footnotetext{
${ }^{65}$ Sovetskii Muzei, No.6, p.33.

66 Ibid, p.34.

67 Ibid, pp.42-43.

68 lbid, p.43-44.

${ }^{69}$ GMPIR F.VI D.45/1, Meeting transcript, p.26.

70 Ibid.
} 
The report and the repercussions were decidedly brutal. The Commission requested a complete review of the staff within a month of the report. Director E.K. Eisenschmidt and his deputy M.B. Kaplan were dismissed as 'socially alien elements'. Most of the dismissed staff were subsequently arrested during the ensuing purges. On a structural level, 'Prison camps and exile' was dissolved as a department. The report demanded a radical reworking of all three remaining departments and to this end, the museum was closed for six months whilst the work was completed. Reconstruction affected all departments. Original documents that were perceived not to fit the desired framework on the history of the CPSU(b) were removed and often hastily replaced with paintings, sculptures and models.

The commission report judged that the museum expositions came into 'conflict with the political situation in the country', whilst 'insufficient attention was paid to the role of party and state figures, historical and party themes' ${ }^{71}$ The inspectors, acutely aware of the tense political climate of the time, saw grave danger in what they felt was the heroization of underground terrorists within the display on the Narodnaya Volya (People's Will). Inspectors would have been fully aware that taking chances was not an option. The timing was critical in this respect; the report was created six months after Sergei Kirov's assassination and shortly after Zinoviev and Kamenev had been forced to admit complicity in the murder and maintaining a terrorist centre in January $1935 .{ }^{72}$ The report examined documents and materials which 'told in the smallest detail how bombs were being prepared' and how the target of the attack was monitored. ${ }^{73}$ This persuaded the inspectors that the museum management were dangerous, especially with the current fears regarding conspiracies and assassinations. ${ }^{74}$ For his role in the creation of the exposition, AV Pribyleva, on the museum council, was arrested in the following purges.

\footnotetext{
${ }^{71}$ Artemov, Experience of the past, p.11.

${ }^{72}$ A. Wood, Stalin and Stalinism, London: Routledge, 1990, pp.36-37.

${ }^{73}$ O.V. Velikanova, 'Stalinizm v mikroistorii razrusheniia Muzeia Revoliutsii v Leningrade' (Stalinism in the Museum of the Revolution in Leningrad), in A.M. Kulegin (ed), GMPIR: 90 years in the space of history and politics. 1919-2009. SPb.: Norma, 2010, pp.96-97.

74 Ibid.
} 
Sergei Avvakumov, a reliable man and an ardent propagandist of communist ideas, was tasked with a significant list of immediate priorities before the planned reopening by November 1935 and the next anniversary of the October Revolution. Highlighting the role of Lenin and the Bolsheviks was perhaps considered his most pressing remit, alongside more emphasis on its struggle against populism, Menshevism and opposition at all stages of the revolution. The role of Stalin during the preparation and victory of the October Revolution also needed more apparent magnification. ${ }^{75}$ Clarity upon the success of Stalin's economic success was also a definite demand. This task was not to wait. One of the first moves by the museum in the following reorganization was contact by GMPIR to museums in Tiflis and Baku, with an urgent request for evidence of the prosperity of farmers, especially depictions of the village before and after collectivization and evidence of new buildings such as schools, theatres and libraries. ${ }^{76}$

Museum staff were clearly shocked by the rapidity of change. 'Communisation' of the museum le to notable dismissals and staff changes, such as A.T. Shakol, one of the 'active creators of the old Museum of the Revolution' since 1919, though changes were not widespread. ${ }^{77}$ For the remaining staff, many in the museum did not admit their guilt, stubbornly refusing to acknowledge their part in what were considered serious methodological errors. In 1960, Avvakumov himself later admitted that the museum's errors depended heavily on the state of 'historical science', and it was 'impossible to blame the museum for academic errors or subjectivity'. ${ }^{78}$ His view was that many of the demands from the report merely stated 'known shortcomings' such as the exaggerated role of populism, which subsequently was placed 'in the shadows'. ${ }^{79}$ Yakovleva saw the older methods far more critically regarding the reformation as clearly necessary. To her mind, 'the old method of exposition represented historical facts on the surface...which created misconceptions about the role

\footnotetext{
${ }^{75}$ V.A. Muzichenko, 'Sergei losifovich Avvakumov: Direktor Gosudarstvennogo Muzeia Revoliutsii', in A.M. Kulegin (ed), GMPIR: 90 years in the space of history and politics. 1919-2009. SPb.: Norma, 2010, p.88.

${ }^{76}$ Velikanova, p.97.

77 Ibid.

${ }^{78}$ GMPIR F.VI D.45/1, Meeting transcript, p.24.

79 Ibid, p.44.
} 
of the individual in history'.$^{80}$ Populist 'heroes' were portrayed 'more vividly and expressively than the leading role of the Communist Party' ${ }^{81}$ Her account however, dates from 1940.

The atmosphere at the time of GMPIR's temporary closure was characterized by class war. Intransigence towards political opponents reigned throughout the USSR. A Short Course of the history of the CPSU(b) had been written and was in the process of being edited by Stalin, who had commissioned the text himself upon the motive that a book was necessary 'instead of the Bible', which would 'give a rigorous answer...to many important questions' ${ }^{82}$ It may have been compiled by a team of historians and party members, most prominently Pyotr Pospelov, Yemelyan Yarovslavsky and Vilhelms Knorins, but Stalin contributed his own chapter about dialectical materialism and was said to have closely supervised the other contributions, making him 'to all intents and purposes...the general editor'. ${ }^{83}$ The book had insurmountable influence over the historiography in the USSR, with museums firmly under scrutiny to reflect the text as the new orthodoxy - especially on the history of the Communist Party and the revolutionary movement. L.D. Pavlova recalled in 1938 that 'the Museum had received a party document, a resolution on the Short Course of the History of the CPSU(b), and this document was the basis...for re-exposure' ${ }^{84}$ The new exposition of the museum was built strictly in accordance with the chapters of the history textbook of the party and actually become an 'illustration of the textbook' ${ }^{85}$

In the height of expectation, Avvakumov reopened the museum with special guests Nadezhda Krupskaya, Maria Illichna Ulyanova and Lenin's nephew, Victor Lozgachev on $23^{\text {rd }}$ October 1935, two weeks before the public reopening. ${ }^{86}$ Leningradskaia Pravda reported that the guests of honour were shown the atmospheric recreation of Lenin's Helsinki room in the October section, set

\footnotetext{
${ }^{80}$ GMPIR F.VI D.45/1, Memories, p.18.

81 lbid.

${ }^{82}$ R Service, A history of Modern Russia: From Nicholas II to Vladimir Putin, Harvard University Press, 2005, pp.237-238.

83 Ibid. Note - the last of which, Knorins, was executed, $29^{\text {th }}$ July 1938 , after his arrest during the Great Purges.

${ }^{84}$ GMPIR, F.VI D.45/1, Report, p.32.

85 GMPIR D. 58 L. 70.

${ }^{86}$ Andrianova, p.72.
} 
during his stay in Helsinki during the Kornilov Affair in August 1917. Krupskaya and Ulyanova also inspected the 'Civil War' department and the panorama of Barricades on Presnya by the artist Babichev in the ' 1905 ' department. ${ }^{87}$ The spectacle, which appeared to pass with relative success, gave way to the full reopening. Despite its closure for almost half of $1935,336,000$ attended that year, followed by 625,000 the following year. ${ }^{88}$

On Avvakumov's initiative, three sections were re-exposed, with a chronological framework from the serf uprisings to the first Russian Revolution. In 1936, Avvakumov planned to the creation of additional departments under the titles; 'From the first revolution to the second' and 'Socialist construction and the Comintern'. A further new exposition, 'The October Socialist Revolution' was completed for the $20^{\text {th }}$ anniversary celebrations, distinguishing it somewhat from the Civil War department. 'Revolution in the West' now required a head of department, whilst the post of 'Artistdesigner' was created, ostensibly to save money. ${ }^{89}$ Work also concentrated on improvements to the artistic design of the museum, including the increased use of models and development in the creation of charts and tables, including new displays which reflected economic development under Tsarist and Soviet Russia.

Sergei Avvakumov's directorship, at least in its early stages, saw three further changes of significance. The first was to establish greater links with the people of Leningrad. Contact was established with collective farms to ensure that farmers who visited the city could attend GMPIR. Arrangements with district party committees were made to further the numbers of people visiting the museum, following up on Avvakumov's demand that more attention be paid to work with factories and plants. He also created the post of 'Head of the Mass Sector', fully prioritising visitor numbers. In 1936-37, the museum achieved its highest numbers yet, 621,485 people, whilst 278,002 of them were 'single visitors' (i.e. not in group tours).$^{90} \mathrm{~A}$ second reform regarded the excursions

\footnotetext{
87 Muzichenko, p.88.

${ }^{88}$ Andrianova, p.73.

${ }^{89}$ Muzichenko, p.89.

90 Ibid.
} 
policy of the museum, as the 'excursion bureau continues to exceed' the rate of excursions per day for each guide. ${ }^{91}$ At this time excursions were not only assigned to the 'mass-awareness' department, but also the research staff. Whether this move was for the wellbeing of staff, or to retain quality standards, is unclear.

A third change, or at least a further development, was the greater attention to visitor relations and their impact on society. Aside from an expansion of projects beyond the museum (see following section), the museum also created visitor questionnaires about each exposition, based on the same pattern for each department. ${ }^{92}$ For researchers (scientific workers), it was also obligatory to provide a review and to enter into the visitor book, in order to provide feedback and give suggestions for potential improvements.

By reviewing the visitor feedback during and following the 'Avvakumov overhaul', an insightful picture can be formed in terms of how effective the communication was between those managing the museum and the visitor. Perhaps predictably, student and teacher entries tended lent towards recognising what had been learned: 'The museum educates young patriots in the spirit of communism and devotion of the Bolshevik Party', whilst 'What I have seen leaves a lasting impression on me. The happy and joyful life we now have in our country is the result of heavy battles of the revolutionary Russian proletariat with the Tsarist autocracy and the Russian bourgeoisie' ${ }^{93} \mathrm{~A}$ visiting teacher recognised the educational value of the museum, praising 'Thank you comrade Stalin and the CPSU(b) for well-equipped museums for teachers and lecturers' ${ }^{94}$ Other visitors besides were keen to make their support very clear amidst the polarized rhetoric of the late 1930's, especially those with a party role. A party deputy visiting from Arkhangelsk is amongst the most forceful on record after his visit, exclaiming 'I want to smash the traitors of the homeland! And build

\footnotetext{
${ }^{91}$ GMPIR, 'Orders for the museum', 17.02.1936-30.12.1936, p.5.

92 Muzichenko, pp.90-91.

${ }^{93}$ GMPIR F.VI, Collected visitor feedback of the Museum of the Revolution (1938-40). Selected entry dated 8.5.1938.

${ }^{94} \mathrm{Ibid}$, 4.3.1939.
} 
communism even more actively'.$^{95}$ Military personnel were just as keen to enjoy the victories of the past; 'We are kings of the world! We are masters of everything and in this house of the Romanovs...today everything is royal dust! Thank you Bolshevik Party! Thank you Lenin and Stalin for our today and tomorrow! ${ }^{96}$

However it was made clear that recent developments in the expositions had not won universal and uncritical praise. 'The halls are well equipped. But the exhibits are a bit monotonous and boring' was one such unsigned judgment. ${ }^{97}$ Another was disappointed about the potential to be educated; 'A lot of confusion. No-one is told anything seeing as there are no guides. You leave the museum and only to a small degree you take away knowledge about the past' ${ }^{98}$ Further comments suggest that the museum was not running as an effective cultural institution. One critic, again leaving an unreadable signature so as not to be identified, concluded; 'The management of palaces and museums need to restore order in the work of museums. The thing is that the administration did not seem to have the purpose to enlighten. Instead they are interested in haggling. Such is the order in all the museums of Leningrad. They need to be changed immediately' ${ }^{99}$ Some criticisms weigh heavy with the politics of the age, showing anger at the representation of individuals who had now been judged as enemies of the people. Similarly, recorded comments, again unsigned, felt entirely the opposite, instead condemning the removal of such persons. They preferred that, as a Museum of the Revolution, to show the past 'how it really was'. ${ }^{100}$

Avvakumov did not remain in post for long, but oversaw a period of immeasurable volatility in the history of the museum. He received an internal order from the Leningrad Committee of the CPSU(b) in December 1936, releasing him from the Museum of the Revolution and instead posting

\footnotetext{
95 Ibid, 14.7.1938.

96 Ibid, 6.7.1938.

97 Ibid (Undated).

98 Ibid, 3.3.1983.

${ }^{99}$ Ibid, 17.3.1938.

100 Ibid (Undated).
} 
him to the Leningrad Museum of Lenin. ${ }^{101}$ During his tenure, the orders of the party had been fulfilled. By the anniversary of October, updated expositions had been installed, in which the theory of the two leaders strengthened the presence of Stalin. The scientific and technical activities of the museum had been given concentrated effort, as had new methods to utilise and design the museum space more effectively. More than ever before, great efforts had been made to attract visitors. Constant reorganization of expositions had incurred significant expenditure however, limiting the full development of the museum in other aspects. After his directorship at GMPIR, Avvakumov's own personal story is a useful, but by no means isolated example of a Soviet academician. After the Lenin Museum, he became director at the Kirov museum and a renowned author on Kirov's life before becoming Head of Propaganda at Leningradskaia Pravda in wartime, in addition to collecting artefacts related to the Siege of Leningrad for the Leningrad Committee of the CPSU(b). ${ }^{102}$ After the war, he worked for the committee as Deputy Head of Propaganda, then at the Institute of History before being arrested for his alleged involvement in the 'Leningrad affair', a series of fabricated criminal cases accusing politicians and party members of treasonous activity. Avvakumov was accused of participating in an Anti-Soviet, Trotskyite group in the mid 1920's. ${ }^{103}$ Despite admitting errors, Avvakumov pleaded not guilty, but nevertheless received a sentence of 25 years in a detention camp in 1950, when he was 56, and his family were exiled from Leningrad. Fortunately he was rehabilitated in June 1954 when his case was considered by Nikita Khrushchev as First Secretary of the Central Committee of the CPSU, returning to party service as a senior researcher and lecturer until his death in $1964 .{ }^{104}$ His life stands as an insightful, but typical case of the era. Despite his long service to the CPSU, including the reorganization of GMPIR, he was given no special treatment

\footnotetext{
${ }^{101}$ GMPIR ‘Orders for the museum', 17.02.1936-30.12.1936, p.35.

102 Muzichenko, p.92.

103 Ibid.

${ }^{104}$ Muzichenko, p.93. Also, GMPIR F.VI D. 2601, Certificate of the Military Collegium of the Supreme Court, Termination of the case against S.I. Avvakumov, Moscow, 20.8.1954, p.1.
} 
during a time of intense suspicion where rapid changes in circumstance were eminently possible. He was also never known to have spoken out against the Party or the government.

The reforms started during Avvakumov's time continued under the acting director, MI Solodnikova and the next permanent director, S.I. Shudenko. The rebuilding of the Civil War department best distils the direction of the museum in these years. Having been redeveloped, the exposition now concentrated on the Bolsheviks during the Civil War, rather than the Civil War in the predominant context of revolutionary struggle. To accomplish this, materials were removed that reflected the activities of other revolutionary leaders, whilst large paintings of Stalin were installed. ${ }^{105}$ Indeed, the use of large works of art acted as the leading exhibits, with Stalin and Dzerzhinsky on the Eastern Front commissioned, whilst the sculptural Stalin, Voroshilov and the Red Army were planned to be at the centre of the new exposition. ${ }^{106}$ In total, 21 original paintings on historical themes, 10 authorized copies from recognized historical paintings and 10 sculptures were introduced into the exposition of the departments on the October Revolution and the Civil War. ${ }^{107}$

The placement of artwork was now central to the exposition, a complete sea change from the original dynamics of the museum creators. Likewise, the new incarnation of the Civil War department reflected the complete adoption of the Short Course of the History of the CPSU(b). Specific importance was given to the role of Stalin during the Civil War, supported by Rudolph Frentz's painting Stalin at the head of the defence of Tsaritsyn and a range of documentary artefacts dedicated to the victorious defence. Numerous materials placed Stalin and Lenin as the 'organizers of victory on the fronts of the Civil War', supplementing the now quite apparent 'two leaders' theory. Materials which recognized other military commanders walked a difficult line from a curatorial perspective. M.V. Frunze, K.E. Voroshilov, S.M. Kirov and others were retained as great 'proletarian' generals, whilst men such as M.N. Tukhachevsky, V.K. Blyukher and I.I. Vatsetis had

\footnotetext{
${ }^{105}$ E.G. Artemov, K voprosu o periodizatsii istorii Muzeia Velikogo Oktiabria (1919-1988 (On the periodization of the Museum of the Great October Revolution), Leningrad, 1989, p.31.

${ }^{106}$ GMPIR D.38 L.9.

107 GMPIR D.58 L.60.
} 
already been declared 'enemies of the people', meaning they had no mention in the expositions. ${ }^{108}$ Likewise, material on the original creator of the Red Army and personal enemy of Stalin, Trotsky, was retained but carefully managed. Documents and photographic evidence lauded the role of legendary heroes who died during the conflict, perhaps most famously VI Chapaev, NA Shchorsa and SG Lazo. ${ }^{109}$ Visually central, and timed to the celebration of the twentieth anniversary of the museum, two great dioramas were created by a team of artists managed by Rudolph Frentz: The storming of the rebellious Red Hill by heroic sailors under the leadership of Stalin and The defeat of Yudenich at Pulkovo Heights in 1919. ${ }^{110}$

Because of the outbreak of war in 1941, 'The Bolshevik Party in the period of foreign intervention and Civil War' turned out to the last 'new' exposition at the Museum of the Revolution. Plans to create a display on 'Socialist Construction' were not completed before 1941. What turned out to be the final years at the Winter Palace also saw further disruption, and permanent losses, to the collections of the museum. In April 1937, the Leningrad City Committee of the CPSU(b) ordered the transference of many materials related to Lenin's life to the Lenin museum, including a funeral wreath and original materials from rooms he stayed in during the revolutionary period. ${ }^{111}$ Later in the same year, the museum was gravely affected by the order 'On the procedure for removing funds of departments, storing and accounting of materials subject to transfer to a special fund' (December 15 $5^{\text {th }}$ 1937). ${ }^{112}$ Harmful materials were to be withdrawn from collections and 'either destroyed...or transferred to a special fund'. ${ }^{113}$ Unsurprisingly, given the ongoing purges, the losses were extreme in the cases of formerly heroic Soviet figures now deemed 'enemies of the people', including Trotsky, Zinoviev, Bukharin and Rykov. Collection purges hit the Civil War materials particularly hard. Portraits and photographs of White Guards and ministers, in the sum of 325 items, were taken in

\footnotetext{
108 GMPIR D.58 L.73.

109 Ibid.

110 Ibid. Also, GMPIR D.58 L.79.

111 Velikanova, p.98.

112 Spiridonov, p.131.

113 Ibid.
} 
late August 1941, as were collections of counterrevolutionary newspapers (Mir, Voice of the Fatherland). ${ }^{114}$ It is also estimated that 215 images of Trotsky from the period of the October Revolution and Civil War were confiscated, with 380 other enemies of the people. ${ }^{115}$

GMPIR in the final years before war was essentially in a redundant position. It could no longer prioritise the preservation and display of authentic historical artefacts, whilst the adoption of the Short Course of the History of the CPSU(b) rendered all expositions standardized. GMPIR, and many Leningrad museums besides, were caught in the position of maintaining duplicate expositions. Upon the outbreak of the Great Patriotic War, the museum closed its doors to visitors. Expositions were dismantled and collections were housed under the ramparts of the Winter Palace. A small team remained to ensure the safe storage of objects and indeed the collection of materials during the siege. Around 17,000 items were collected related to the war. ${ }^{116}$ Meanwhile, regular travelling exhibitions and lectures continued to be organized until the end of the war in the USSR in 1945.

Following the most tumultuous year in the history of the Leningrad Museum of the Revolution, with its closure, change in directorship and radical exposition overhaul, the first attempt was made to remove GMPIR from the Winter Palace in $1936 .{ }^{117}$ The Director of the Hermitage, losif Orbeli, wrote directly to Stalin and requested that GMPIR be evicted in order to provide for the expansion of the Hermitage. This was not prioritised before the war, but a second attempt won the support of the Leningrad Soviet in 1945. Despite stubborn resistance from the museum or the People's Commissariat of Education, the decision held. No alternative premises were found, despite several being considered, namely the Sheremetev Palace, Mikhailovsky Castle and the Beloselsky-Belozersky

\footnotetext{
${ }^{114}$ GMPIR, Acts and Correspondence on the cancellation of exhibits, the insurance and receipt of exhibits for permanent and temporary use, the transfer of documents to the archives and completion of work to verify the availability of museum funds, June 1936-December 1951, No.1: 27.12.1937.

$115 \mathrm{Ibid}, 30.8 .1941$.

${ }^{116}$ Velikanova, p.98.

${ }^{117}$ Artemov, Experience of the past, p.12.
} 
Palace. Instead, soldiers packed the belongings of the museum into boxes in February 1946. Without a 'home', these years saw the worst of the purges upon the GMPIR collections. In the following five years, huge photographic and document collections were destroyed, including leaflets published by Denikin and Kolchak during the Civil War, and signed Trotsky documents. In 1951 alone, 12,000 documents were destroyed, including 1,039 on the history of the White movement. ${ }^{118}$ The number of original artefacts relating to non-Bolshevik forces during the Civil War era was now barely notable, and the same could be said of members of the first Soviet government. With a significantly reduced staff, for ten years the artefacts and possessions of the museum would be stored in the attics of the Marble and Stroganov Palaces, and in the Peter and Paul Fortress, which became its main platform.

It was not until 1956 that the Leningrad State Museum of the Great October Revolution was opened. By this time, many had no idea that the museum had been created over thirty-five years ago and had been one of the most popular in the city for several decades. ${ }^{119}$ In fact, over 10 million people had visited the Museum of the Revolution in its first two decades (prior to the outbreak of war) at the Winter Palace site alone. ${ }^{120}$ By 1927 , aside from the Hermitage and the Russian Museum, it was the most visited museum in Leningrad $(346,000)$, and if branches were included, it outstripped even them $(598,000) .{ }^{121}$ Even without considering the numerous branches established by GMPIR, visitor numbers in the late 1930's had reached close to a million people per year, peaking at 832,000 in 1937. By 1941, even taking into account the purges of artefacts and documents that had already occurred, the museum had amassed a collection of artefacts numbering 30,000 items, 58,000 newspapers and 52,000 magazines and journals. As things stood prior to the war, the museum was seen as prestigious. They occupied some of the grandest and most emotive buildings and revolutionary sites in Russia. Certainly for Leningrad, if not the Soviet Union, it was at the high point

\footnotetext{
${ }^{118}$ A.G. Kalmykov, 'Tekhnologiia ispravleniia istorii' (The technology of correcting history), in Yearbook of the St Petersburg Society of Historians and Archivists, St. Petersburg, 2000, pp.332-335. in Spiridonov, p.131. ${ }^{119}$ Velikanova, p.95.

120 GMPIR F.VI D.45/1, p.6.

${ }^{121}$ Velikanova, p.96.
} 
of the hierarchy on revolutionary history until Moscow greater precedence in the 1930's. Employees were recognized as an authority on their subjects and welcomed to factories, schools and academic institutes as such. ${ }^{122}$ In short, it was a powerful cultural, educational and ideological institution.

Yet the Museum of the Revolution's institutional authority was frequently undermined. It constantly struggled to find a period of stability in which it could attempt to execute its enlightenment function. It may have gloriously been given the prestigious surroundings of the Winter Palace, support from some of the most powerful party figures and the status of being the world's first museum on Marxism, but it was not given special treatment. From the outset, funds allocated to the Museum by the People's Commissariat for Education did not suffice, leaving the museum to appeal to the Petrograd Soviet in cases of emergency. ${ }^{123}$ Staff wages, which were very modest, were only just covered by the state budget allocation. Entrance fees from the public quickly caught up with the finances from the state budget. Maintenance costs formed a frequent source of bother, with the museum having to request more money from the state budget when shortcomings were revealed in terms of fire safety. ${ }^{124}$ In the same year (1929), the condition of electricity in the buildings left the Winter Palace without light halting the work of the museum entirely. The late 1920's also saw the expansion of the museum's remit in terms of branches. When the Shlisselburg was added as a branch, the museum was so in need of restoration funds that Glavnauka allowed the museum to sell off items considering 'unnecessary inventory' in order to fund 'necessary repairs on historical buildings' ${ }^{125}$ Despite the ideological significance of GMPIR, ambitions for its purpose were out of step with the unstable financial position and ultimately the lack of privileges it was allowed.

Spiridonov wrote that 'history has long been a powerful means of political propaganda, so it is understandable that every new Head of State considers, if not to rewrite history, then at least to

\footnotetext{
122 Andrianova, p.75.

${ }^{123}$ Leikina-Svirskaia, p.58.

124 TsGALI StP F.285 O.1 D.5 L.13.

125 TsGALI StP F.285 O.1 D.3 L.10.
} 
correct it based on current political tasks'. ${ }^{126}$ This position recognises the realities of Soviet institutional life in the 1920's, and even more so in the decade that followed. For the most part, the significant changes in the approach of the GMR to its role were directly the results of socio-political circumstances rather than pedagogical developments. As a case in point, the Civil War department of the GMR stands as evidence. The original exposition of the early 1920's was perhaps the 'most objective demonstration of the history (of the Civil War) for the entire Soviet period of the museum's existence'. ${ }^{127}$ At this stage, the museum was based heavily on authentic exhibits and the guiding principles were quite simple - to be clear, to provoke emotion and to be accessible for masses of visitors. Reconstruction came about as a result of external factors, beginning with the First Museums Congress in late 1930. Yet in reality, sweeping changes had already happened in other branches of academic thought, preceding the Congress. During the first years of collectivization and the First Five Year Plan, non-Marxists had suffered reprisals and arrests, whilst Marxist scholars were engaged in a struggle to win the mandate from the Central Committee to 'guide the professions'. ${ }^{128}$ Exactly two years before the First Museums Congress, the All-Union Congress of Marxist Historians waged war in a campaign against non-Marxist historians, based on a belief that non-Marxists were in league with bourgeois specialists and wealthy peasants. The result was the termination of numerous scholarly organizations and greater control over others, including the Academy of Sciences. The historical profession in the early 1930's in Soviet Russia was indicative of the wider 'pathetic servitude of scholarship'. ${ }^{129}$ This only intensified following Stalin's own intervention in 1931 concerning historical scholarship in Proletarskaia Revoliutsiia, which effectively set the tone for a protracted period of historical orthodoxy. ${ }^{130}$ Historians were certainly as likely to suffer as anyone during the Stalinist purges. The aforementioned Marx Engels Institute endured a purge of staff who

\footnotetext{
${ }^{126}$ Spiridonov, p.127.

127 Ibid.

${ }^{128} \mathrm{G}$. Emteen, Soviet historians and the study of Russian imperialism, Pennsylvania State University Press, 1979, pp.15-16.

129 Ibid, p.23.

130 Ibid, p.24.
} 
were deemed ideologically suspicious following the trial and exile of the head of the institute, David Riazanov, who had been accused of hiding Menshevik documents in the facility. ${ }^{131}$ The institute was promptly restructured and merged into the larger Lenin Institute in November 1931.

The process present in the revision of Soviet history, now centring on Stalin, deviating from world revolution and the cleansing of social spaces, undoubtedly dictated the Museum of the Revolution in the 1930's. The shifting ethos of the museum, especially when overlooking the full extent of the period from GMR's establishment and the outbreak of war, was from revolutionary culture to pompous chauvinism; spontaneity to conservatism, with manicured collections. ${ }^{132}$ Fitting with these overarching trends might perhaps suggest that we would be right in perceiving the GMR as a case study not worthy of analysis, but this would be far from the case. Particularly in the 1920's, the GMR showed remarkable evidence of innovation, specialism and visitor popularity. It represented a genuine attempt to record the history of the revolutionary movement in a way that could touch the hearts and minds of all those who attended, whether by displaying gathered and donated materials with remarkable speed, or by the originality provided by its association with revolutionary veterans and those who had been scarred by the Tsarist regime. Initially, it was also a setting whereby a shared investment from across the anti-Tsarist divide could be recognized, with the original collegium containing non-Bolsheviks and academics without a revolutionary heritage or persuasion. This trend was true of parallel developments involved in the process of 'institutionalising October', with only a third of the staff (39 of 109) at the Marx Engels Institute were members of the Communist Party, despite being under their watchful eye, at the end of the 1920 's. ${ }^{133}$ The museum was also a hub of civic activism in its early stages, whilst perhaps best evidenced by the independent Society of Former Political Prisoners and Exiles, this was by no means a lone example. The founding fathers of the museum and this society were effectively revolutionary veterans - most

\footnotetext{
131 Barber, p.122.

132 Velikanova, p.95.

133 Barber, p.16.
} 
notably Mikhail Novorusskii, who helped form the bulk of the original collection of the GMR.

Additionally, even prior to the imposition of greater hierarchy and central control, the museum had built a strong profile with local academic institutions, workers organizations and schools, without significant interference. All of this was done with extraordinary levels of challenge, mostly as a result of increasing responsibility (including more branches) and severe shortages of funding, and to some extent, expertise.

Elsewhere, other comparative efforts to curate the history of the revolutionary movement faced major challenges after initial impetus. Istpart efforts to coordinate an integrated revolutionary and party history faced institutional confusion and rivalry. They were still complaining about the failure of bureaus to bring together a coherent, integrated project in 1925, five years after their creation. Their conclusion was blunt: 'Almost nothing (had been done)...to systematically elucidate the history of the party', whilst the Moscow bureau derided others for failing to get across the 'basic principles of the organization of $1917{ }^{\prime}{ }^{134}$ These failings ultimately saw their functions absorbed into the Marx Engels Institute after its dissolution in 1928, just one year before the GMR had been forced to lose much of its archival material on revolutionary history to Moscow. ${ }^{135}$ Even if we accept that the goals of a realized, satisfactory narrative of recent revolutionary history had not been achieved within the first decade, the lack of counter-narratives assisted multiple opportunities to see and hear an 'October retelling'. Corney concluded that the combined institutional efforts meant that it was 'no longer necessary to have been present at the historical events' to recognize their fundamental importance for Soviet citizens. ${ }^{136}$

Originality and an enthusiastic desire to use the realities of the revolutionary struggle to engage visitors, the attributes which had enabled the museum to build a significant reputation during the 1920 's, became variables that invited centralized control by the beginning of the 1930's. In the case

\footnotetext{
${ }^{134}$ Corney, pp.142-143.

135 Barber, p.16.

${ }^{136}$ Corney, pp.201-202.
} 
of the masonic exhibits within the displays on the Decembrists, or the explanation of explosives associated with the People's Will, we can see seeds of what was rooted out by the didacticism of the Short Course of the History of the CPSU(b) and indeed the dictated changes in the museum after its closure in 1935 . The museum no longer celebrated the achievements of the revolutionary struggle in an emotive, personalized way, but it became an effective purveyor of revolutionary orthodoxy under Stalin. Undoubtedly one could hold that it reached far more people as a result, but it had already lost many of the valuable attributes that had contributed to its success. There was no willing engagement from voluntary societies, the humanity of revolutionaries giving tours had been phased out and ambiguity or independence from different museum departments and branches was no longer visible. Any variables in the way expositions could be constructed or told via excursions had been removed, and the opportunity to hear visitor feedback without the foreboding sense of being watched had also been erased. 